\title{
Dietary Protein, Weight Loss, and Weight Maintenance
}

Citation for published version (APA):

Westerterp-Plantenga, M. S., Nieuwenhuizen, A., Tome, D., Soenen, S., \& Westerterp, K. R. (2009). Dietary Protein, Weight Loss, and Weight Maintenance. Annual Review of Nutrition, 29, 21-41. https://doi.org/10.1146/annurev-nutr-080508-141056

Document status and date:

Published: 01/01/2009

DOI:

10.1146/annurev-nutr-080508-141056

Document Version:

Publisher's PDF, also known as Version of record

Document license:

Taverne

Please check the document version of this publication:

- A submitted manuscript is the version of the article upon submission and before peer-review. There can be important differences between the submitted version and the official published version of record.

People interested in the research are advised to contact the author for the final version of the publication, or visit the DOI to the publisher's website.

- The final author version and the galley proof are versions of the publication after peer review.

- The final published version features the final layout of the paper including the volume, issue and page numbers.

Link to publication

\footnotetext{
General rights rights.

- You may freely distribute the URL identifying the publication in the public portal. please follow below link for the End User Agreement:

www.umlib.nl/taverne-license

Take down policy

If you believe that this document breaches copyright please contact us at:

repository@maastrichtuniversity.nl

providing details and we will investigate your claim.
}

Copyright and moral rights for the publications made accessible in the public portal are retained by the authors and/or other copyright owners and it is a condition of accessing publications that users recognise and abide by the legal requirements associated with these

- Users may download and print one copy of any publication from the public portal for the purpose of private study or research.

- You may not further distribute the material or use it for any profit-making activity or commercial gain

If the publication is distributed under the terms of Article $25 \mathrm{fa}$ of the Dutch Copyright Act, indicated by the "Taverne" license above, 


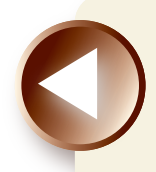
ANNUAL Further

Click here for quick links to Annual Reviews content online, including:

- Other articles in this volume

- Top cited articles

- Top downloaded articles

- Our comprehensive search

Annu. Rev. Nutr. 2009. 29:21-41

First published online as a Review in Advance on April 28, 2009

The Annual Review of Nutrition is online at nutr.annualreviews.org

This article's doi:

10.1146/annurev-nutr-080508-141056

Copyright (c) 2009 by Annual Reviews. All rights reserved

0199-9885/09/0821-0021\$20.00

\section{Dietary Protein, Weight Loss, and Weight Maintenance}

\author{
M.S. Westerterp-Plantenga, ${ }^{1,2}$ A. Nieuwenhuizen, ${ }^{1,2}$ \\ D. Tomé, ${ }^{3}$ S. Soenen, ${ }^{1,2}$ and K.R. Westerterp ${ }^{1,2}$
}

${ }^{1}$ Department of Human Biology, Nutrim, Faculty of Health, Medicine, and Life Sciences, Maastricht University, $6200 \mathrm{MD}$, Maastricht, The Netherlands; email: m.westerterp@hb.unimaas.nl

${ }^{2}$ TIFN, 6700 AN Wageningen, The Netherlands

${ }^{3}$ AgroParisTech, Department of Life Sciences and Health, UMR914 Nutrition Physiology and Ingestive Behavior, F75005, Paris, France

\section{Key Words}

satiety, energy expenditure, substrate oxidation, body composition, protein metabolism

\section{Abstract}

The role of dietary protein in weight loss and weight maintenance encompasses influences on crucial targets for body weight regulation, namely satiety, thermogenesis, energy efficiency, and body composition. Protein-induced satiety may be mainly due to oxidation of amino acids fed in excess, especially in diets with "incomplete" proteins. Proteininduced energy expenditure may be due to protein and urea synthesis and to gluconeogenesis; "complete" proteins having all essential amino acids show larger increases in energy expenditure than do lower-quality proteins. With respect to adverse effects, no protein-induced effects are observed on net bone balance or on calcium balance in young adults and elderly persons. Dietary protein even increases bone mineral mass and reduces incidence of osteoporotic fracture. During weight loss, nitrogen intake positively affects calcium balance and consequent preservation of bone mineral content. Sulphur-containing amino acids cause a blood pressure-raising effect by loss of nephron mass. Subjects with obesity, metabolic syndrome, and type 2 diabetes are particularly susceptible groups. This review provides an overview of how sustaining absolute protein intake affects metabolic targets for weight loss and weight maintenance during negative energy balance, i.e., sustaining satiety and energy expenditure and sparing fat-free mass, resulting in energy inefficiency. However, the long-term relationship between net protein synthesis and sparing fat-free mass remains to be elucidated. 


\section{Contents}

INTRODUCTION ................

PROTEIN-INDUCED SATIETY

BY ACUTE HIGH-PROTEIN

MEALS AND MEDIUM-TERM

HIGH-PROTEIN DIETS.

Acute High-Protein

Meal-Induced Satiety ..........

High-Protein Diet-Induced

Satiety..................... 26

ENERGY EXPENDITURE......... 27

Protein Intake and Diet-Induced

Energy Expenditure........... 27

Protein Intake and Sleeping

Metabolic Rate ...............

Protein Intake and Protein

Turnover . . .

PROTEIN AND AMINO

ACID METABOLISM,

GLUCONEOGENESIS, AND

GLYCOGEN SYNTHESIS .......

Protein Turnover and

Metabolism..................

Gluconeogenesis............... 30

BODY WEIGHT AND BODY

COMPOSITION

Protein Intake and Energy Intake... 31

Sustained-Protein Diets

for Body-Weight Loss.......... 32

Sustained Relatively High-Protein

Diets for Body-Weight

Maintenance............... 33

POTENTIAL RISK OF

HIGH-PROTEIN DIETS........ 34

HYPOTHESES TO BE

ASSESSED.

CONCLUSIONS

\section{INTRODUCTION}

Obesity is a major health problem with serious comorbidities $(70,78)$. Weight loss is usually achieved more readily than weight maintenance after body weight loss $(70,107)$. Conditions for weight maintenance after weight loss are $(a)$ sustained satiety despite negative energy balance,

(b) sustained basal energy expenditure despite body weight loss, due to $(c)$ sparing of fat-free mass, which is the main determinant of basal energy expenditure.

Diets with a relatively high-protein content act on these metabolic targets (3). Doubling the relative protein content of the diet from the normal level of 10 to 15 en $\%$ to 20 to 30 en \% reduces food intake under ad libitum conditions, resulting in immediate body weight loss. In the long term, body weight reaches a new value at a significantly lower level. Thus, an increase in the relative protein content of the diet, irrespective of protein type, reduces the risk of a positive energy balance and the development of overweight. Increasing protein intake also increases the chance of maintenance of body weight after weight loss induced by an energy-restricted diet. One of the mechanisms contributing to successful maintenance is a sparing effect of fat-free mass, reducing the weight loss-induced decrease of energy expenditure.

This review deals with the effects of relatively high-protein diets during energy balance, weight loss, and weight maintenance thereafter on specific metabolic targets: satiety, energy expenditure, protein and amino acid metabolism, and gluconeogenesis. Effects on body weight and body composition are highlighted, and potential risks of high-protein diets are discussed. Where possible, we take into account the type and quantity of protein, administration of protein, timing of effects, characterization of subjects, energy balance, and duration of studies.

Normal- and high-protein diets need to be defined in relatively and absolutely nor$\mathrm{mal} /$ high protein diets in relation to energy balance (Table 1). Relatively high-protein diets for weight loss and weight maintenance thereafter consist of at least $25 \%$ to $30 \%$ of energy from protein; thus, normal protein intake remains as it was before the diet while total energy intake is decreased (see Table 1). Such diets are relatively high in protein, expressed as percentage energy from protein; however, in absolute terms ( $\mathrm{g}$ of protein) they contain only a sufficient absolute amount of protein and less energy in total. The absolute amount of protein 
Table 1 Absolute or relative "normal"- or "high"-protein diets

\begin{tabular}{l|l|l}
\hline & \multicolumn{1}{|c|}{ Relative energy\% of protein } & \multicolumn{1}{c}{ Absolute g protein } \\
\hline Energy balance & & e.g., $12 \mathrm{MJ} / \mathrm{d}$ \\
\hline Normal & $10 \%-15 \%(\mathrm{WHO})$ & $1.2-1.8 \mathrm{MJ} / \mathrm{d}=67-100 \mathrm{~g} / \mathrm{d}$ \\
\hline High & $18 \%-30 \%$ & $2.2-3.6 \mathrm{MJ} / \mathrm{d}=120-200 \mathrm{~g} / \mathrm{d}$ \\
\hline Negative energy-balance & & e.g., $2 \mathrm{MJ} / \mathrm{d}$ \\
\hline "Normal" & $10 \%-15 \%$ & $0.2-0.3 \mathrm{MJ} / \mathrm{d}=11-17 \mathrm{~g} / \mathrm{d}$ \\
\hline "High" & $47 \%(\mathrm{VED})$ & $0.9 \mathrm{MJ} / \mathrm{d}=52 \mathrm{~g} / \mathrm{d}$ \\
\hline Positive energy-balance after weight-loss & & e.g., $8 \mathrm{MJ} / \mathrm{d}$ \\
\hline "Normal" & $10 \%-15 \%$ & $0.8-1.2 \mathrm{MJ} / \mathrm{d}=44-67 \mathrm{~g} / \mathrm{d}$ \\
\hline
\end{tabular}

Example of calculated grams of protein ingested when relatively normal- or high-protein diets are consumed in energy balance of, for example, $12 \mathrm{MJ} / \mathrm{d}$, or in negative energy balances of, respectively, $2 \mathrm{MJ} / \mathrm{d}$ as during a very-low-energy diet (VLED), or $8 \mathrm{MJ} / \mathrm{d}$ as during a weight-maintenance diet thereafter. The example shows that during a "high"-protein energy-restricted diet, absolute protein intake in the given ranges is still in the originally "normal" range. WHO, World Health Organization.

is the same in a relatively normal-protein diet (10\% to $15 \%$ of energy from protein) in neutral-energy balance (energy intake matches energy requirement set by energy expenditure) as in a relatively high-protein $\operatorname{diet}(20 \%$ to $30 \%$ of energy from protein) in negative-energy balance (energy intake is lower than energy requirement set by energy expenditure) when subjects consume, for instance, only half of their energy requirements in order to lose body weight.

\section{PROTEIN-INDUCED SATIETY BY ACUTE HIGH-PROTEIN MEALS AND MEDIUM-TERM HIGH-PROTEIN DIETS}

A hierarchy prevails for the satiating efficacies of the macronutrients protein, carbohydrate, and fat, with protein being the most satiating and fat the least satiating. This sequence also represents the priority with respect to metabolizing these macronutrients $(97,107)$. In daily life as well as in many experiments, mixed proteins are consumed from meat, fish, dairy products, or plants. A dose-dependent satiating effect of mixed protein has been shown, with quite a range of concentrations of protein offered acutely, in a single meal, to subjects who are in energy balance and are weight stable $(83,97,107)$. In addition, persistent protein-induced satiety is shown when a mixed high-protein diet is given for 24 hours up to several days $(48,49,106)$. Acute, high-protein meal- or drink-induced satiety and mediumterm, high-protein diet-induced satiety are discussed in this section. Mechanisms contributing to protein-induced satiety are considered.

\section{Acute High-Protein Meal-Induced Satiety}

This section focuses on acute protein-induced satiety with single meals, with contents of $25 \%$ to $81 \%$ of energy from mixed protein or specific proteins, followed by subsequent energyintake reduction (97). Given the average "normal" protein intake range of $10 \%$ to $15 \%$ of energy, meals with an average of $20 \%$ to $30 \%$ of energy from protein are representative of high-protein diets when consumed in energy balance (107). Using these protein levels, Smeets et al. (83) examined healthy volunteers with a body mass index (BMI) of $23.8 \pm$ $2.8 \mathrm{~kg} / \mathrm{m}^{2}$ and a percentage body fat of $26 \pm 8.9$ and showed that after a high-protein lunch, satiety and energy expenditure were significantly higher than after a normal-protein lunch, without differences in ghrelin and peptide tyrosintyrosin (PYY) responses. The lower glucagonlike peptide 1 (GLP-1) response following the high-protein lunch is due to the comparison 
with the high-carbohydrate-induced GLP-1 response during the normal-protein lunch, showing clearly that a GLP-1 response is primarily nutrient related and only secondarily satiety related (83).

The satiating power of a high-protein meal is optimized when timing of the interval between the first administration of a meal containing protein (versus control) and the subsequent test meal synchronizes with timing of the amino acid profiles following protein intake (50), ghrelin concentrations (92-97), or visual analogue scale (VAS) satiety ratings (92-97). Ratings on a $100 \mathrm{~mm}$ VAS represent feelings of satiety, hunger, fullness, or desire to eat as detected by the subject. Questions related to appetite profile are anchored with the extreme negative and positive ratings. A point on the scale then gives the value of hunger, satiety, etc. Veldhorst et al. (92-97) timed test meals beforehand, by running the experiments in healthy normal-weight subjects (BMI $23.9 \pm 0.3 \mathrm{~kg} / \mathrm{m}^{2}$ ) twice: first determining the moment when differences in satiety or ghrelin concentrations were still significantly present, then offering the test meal at that moment in the next experiment. Outcomes appear to differ due to the type or quantity of protein intake, or both. For instance, higher satiating effects due to higher concentrations of casein (93) or soy (94) (25 en\% versus 10 en\%) appear to be related to kinetics of amino acid profiles $(93,94)$. Also, with whey as a single protein in a specifically standardized custard breakfast, energy intake was decreased by $13 \%$ at three hours after a breakfast with whey containing glyco-macropeptide (GMP) compared to energy intake after a breakfast with whey not containing GMP, irrespective of whether the whey-protein content was $10 \%$ or $25 \%$ of energy in the custard breakfast. This decrease in energy intake coincided with increased concentrations of certain amino acids, e.g., serine, threonine, alanine, and isoleucine (92). In a comparison of the effects of seven different proteins, in two different concentrations, on energy intake during the subsequent meal, Veldhorst et al. (97) showed (in the same healthy normalweight subjects mentioned above) a more satiating effect from incomplete proteins, i.e., proteins that lack some essential amino acids, versus complete proteins, which contain the essential amino acids. At the level of $10 \mathrm{en} \%$ and of $25 \mathrm{en} \%$ from one type of protein consumed with a breakfast custard, energy intake at lunch was about $20 \%$ less after an alpha-lactalbumin or gelatin with or without added tryptophan breakfast, compared with after a casein, soy, or whey breakfast; differences in energy intakes of about $20 \%$ were a function of differences in satiety ratings of about $40 \%$ (97). In an assessment of different proteins and hydrolysates, Diepvens et al. (19) showed in healthy overweight subjects (BMI $27.6 \pm 1.7 \mathrm{~kg} / \mathrm{m}^{2}$; body fat $\% 32.6 \pm 7.9$ ) indications of lower hunger and desire to eat or higher satiety after consumption of pea protein hydrolysate $(\mathrm{PPH})$ or whey protein (WP) compared to milk protein (MP) or WP + PPH. As mentioned above, effects on relevant hormones were primarily nutrient related. Cholecystokinin (CCK) and GLP-1 concentrations were relatively more increased by MP, whereas PYY concentrations were relatively more elevated and ghrelin concentrations more reduced by WP + PPH (19). No effect on energy intake was seen (19). A similar effect of protein consumption on PYY concentration changes was shown by Batterham et al. (4), who observed significantly higher plasma PYY responses to a high-protein meal in both lean and obese subjects.

With respect to different fractions of protein, such as alpha-lactalbumin or betalactoglobulin, Pichon et al. (69) showed that food intake and body weight gain are significantly lower in rats fed a diet containing betalactoglobulin, which is unrelated to palatability.

When different proteins or amino acids are consumed at very high levels, satiety is very high and differences in satiating effects are no longer observed. For instance Bowen et al. $(11,12)$ reported no difference between effects of casein and whey protein, with high-protein meals inducing a larger satiating effect than high-carbohydrate meals in healthy normalweight subjects. Furthermore, they noted different appetite-regulatory hormone responses 
after whey, soy, or gluten preload despite similar reductions in ad libitum energy intake (12). In a study of food intake in healthy normal-weight to overweight (BMI $25 \pm 1.5 \mathrm{~kg} / \mathrm{m}^{2}$ ) subjects, Burton-Freeman et al. (13) did not find a difference at the test meal between the conditions with preloads consisting of whey with or without GMP, whereas CCK release coincided with the magnitude of satiety ratings.

Effects of protein-containing drinks versus control drinks appear when sufficient protein and energy are present in the drinks. A comparison of isoenergetic dairy fruit drink preloads $(300 \mathrm{~mL} 1.25 \mathrm{MJ})$ differing in macronutrient composition in normal-weight men (BMI $22.6 \pm 0.4 \mathrm{~kg} / \mathrm{m}^{2}$ ) revealed significantly less energy consumption at lunch 120 minutes after the protein $(3.2 \mathrm{MJ})$ than after the control $(3.5 \mathrm{MJ})$ and carbohydrate $(\mathrm{CHO})$ preloads (3.6 MJ), without complete energy-intake compensation (7). A study comparing the effects of a sugar-sweetened beverage (cola) and a chocolate milk drink (0.9 MJ, $500 \mathrm{~mL})$ in healthy subjects (BMI $22 \pm 2 \mathrm{~kg} / \mathrm{m}^{2}$ ) showed that satiety and fullness were significantly greater 30 minutes after consumption of chocolate milk than after cola, although no significant difference in energy intake occurred during lunch (3.2 MJ after chocolate milk versus 3.3 MJ after cola) (35). Soenen et al. (84) found no difference in effects on appetite, energy intake, and energy intake compensation 50 minutes after consumption of $800 \mathrm{ml} 1.5 \mathrm{MJ}$ milk, or carbohydrate drinks in their study of 40 young healthy normal-weight (BMI $\left.22.1 \pm 1.9 \mathrm{~kg} / \mathrm{m}^{2}\right)$ men and women. A study of normal-weight and obese boys showed that 60 minutes after consumption of glucose and whey-protein drinks (250 mL 3.5 MJ), food intake was suppressed more by whey protein $(2.7 \mathrm{MJ})$ than by glucose $(3.1 \mathrm{MJ})$ or control (3.6 MJ) drinks (6). Taken together, these results indicate that there is a bandwidth in protein amount and concentrations in which relatively more protein is more satiating and promotes less energy intake, supported by relatively elevated amino acid concentrations, anorexigenic hormones, or energy expenditure feeding back on the central nervous system. Mellinkoff (58) suggested as early as 1956 that an elevated concentration of blood or plasma amino acids, which cannot be channeled into protein synthesis, serves as a satiety signal for a food intake-regulating mechanism and thereby results in depressed food intake.

There may be some specificity in the effects of individual amino acids on satiety since specific amino acids also serve as precursors for specific neurotransmitters involved in appetite or body-weight regulation or directly influence biochemical pathways involved in eating behavior. For instance, the amino acid tryptophan may act as a precursor for the neurotransmitter serotonin (113). It has been suggested that brain serotonin is involved in appetite regulation (47), a hypothesis that is supported by the anorexigenic effects of serotonergic drugs in humans $(32,91)$. Several dietary intervention studies have attempted to increase brain serotonergic activity, mainly through increasing central tryptophan availability $(5,51,52,113)$. Tryptophan transport to the brain is facilitated by the socalled L-transporter, which also facilitates the transport of other large neutral amino acids (LNAAs), valine, leucine, isoleucine, tyrosine, and phenylalanine in a competitive manner $(8,113)$. Therefore, brain tryptophan uptake may depend not only on plasma tryptophan concentrations, but also on the plasma ratio of tryptophan to the sum of these other LNAAs $(8,113)$. The whey peptide alphalactalbumin contains relatively high levels of tryptophan and has been shown to increase plasma tryptophan concentrations and plasma tryptophan/LNAA ratio when ingested alone $(5,51,52)$ or as part of a meal (8). Indeed, an alphalactalbumincontaining breakfast suppressed hunger more than did a breakfast containing gelatin (which contains very low levels of tryptophan) (64). However, tryptophan addition to the gelatincontaining breakfast did not affect hunger ratings. Also, plasma concentrations of tryptophan as well as the plasma tryptophan/LNAA ratio were not related to hunger. Therefore, these data suggest that tryptophan (and hence, serotonin) is unlikely to play a role in this effect (64). 
In a test of the same hypothesis, Koren et al. (45) studied healthy overweight subjects (BMI $27 \pm$ $2.3 \mathrm{~kg} / \mathrm{m}^{2}$ ) and concluded that an increase in either carbohydrate or protein intake increases satiety and leads to significant weight loss independent of an increase in plasma concentration of tryptophan or the tryptophan/LNAA ratio.

Likewise, the amino acid tyrosine can be converted into the neurotransmitters dopamine and norepinephrine, both of which have shown to be involved in food-intake regulation (101). Although alterations in tyrosine metabolism have been observed in eating disorders such as anorexia (1), there is no direct evidence of a role for tyrosine in protein-induced satiety. A third amino acid that functions as a precursor for a neurotransmitter is histidine, which can be converted into the anorexigenic neurotransmitter histamine (62). Histamine is suggested to decrease food intake through activation of hypothalamic H1 receptors since the anorectic effect of histamine can be blocked by the H1-receptor antagonist $\alpha$-fluoromethylhistidine (FMH) (62). Studies of rats show that increasing the amount of dietary histidine reduces food intake; this can be (partially) prevented by simultaneous administration of FMH, which indicates that histamine plays a role in the effects of histidine on eating behavior $(30,42)$.

With respect to central regulation, Faipoux et al. (24) showed that in rats, protein-induced satiety is related to vagal feedback to $(a)$ the nucleus tractus solitarius in the brainstem, where it represents satiety at almost a reflex level, and (b) the hypothalamus, where it suppresses feelings of hunger (24).

It has been suggested that an elevated concentration of blood or plasma amino acids can be directly recorded by specific areas in the hypothalamus. Intracerebroventricular (ICV) administration of leucine or an increase in dietary leucine reduces food intake and body weight and improves glucose and cholesterol metabolism in rats and mice $(16,114)$. This effect is specific to leucine since leucine alone has the same effect on food intake as does a mixture of amino acids (63). It has also been shown that the adenosine monophosphate (AMP)activated protein kinase (AMPK) and the mammalian target of rapamycin (mTOR) are involved in the satiety induced by high-protein diets (77). It was shown that both a high-protein diet and ICV leucine administration suppress AMPK and ACC phosphorylation in the hypothalamus in rats, which is concomitant with a decreased AMP-to-adenosine triphosphate (ATP) ratio. In parallel, mTOR, an intracellular signaling molecule sensitive to both amino acid and growth factors, was also described as a metabolic sensor. High-protein diet as well as ICV administration of free amino acids or of leucine alone led to an activation of mTOR in the hypothalamus $(63,77)$. High-protein diets modulate AMPK and mTOR in the same specific neuronal subset, the arcuate and paraventricular nuclei of the hypothalamus (ARC and PVN, respectively). AMPK and mTOR may have overlapping and reciprocal functions $(16,63,77)$. The activation of $m$ TOR and the suppression of AMPK phosphorylation activity seem to modulate hypothalamic neuropeptides, including a decrease in neuropeptide Y (NPY) and Agouti-related peptide (Agrp), both orexigenic neuropeptides, and an increase in pro-opiomelanocortin (POMC), which is anorexigenic.

\section{High-Protein Diet-Induced Satiety}

When high-protein menus are offered to subjects at each meal for a duration of one to several days, the metabolic reactions of a high-protein diet are established $(49,97,107,108)$. In several studies of high-protein diets in normalweight healthy subjects, a continuously higher satiety was shown throughout the day after consumption of the high-protein diet in comparison with the normal-protein diet including in the energy-balance-controlled environment of a respiration chamber $(49,97,107,108)$. Here, a normal-protein diet given in energy balance contains $10 \%$ to $15 \%$ of energy from protein (107), and a high-protein diet in energy balance contains $20 \%$ to $30 \%$ of energy from protein (107). A high-protein diet in the 
presence of carbohydrate stimulates GLP-1 release $(49,108)$, which triggers insulin release. More importantly, only high-protein diet-induced satiety is primarily related to elevated energy expenditure (49, 97, 107, 108), which implies that oxygen consumption and body temperature increase, leading to a feeling of being deprived of oxygen and thus promoting satiety $(97,107)$. Energy expenditure is different due to different protein sources and is mediated by the high ATP costs of postprandial protein synthesis; digestion rate also plays a role (107). Moreover, substrate oxidation changes during high-protein diets, in that less protein is oxidized than is consumed, resulting in a positive protein balance, and more fat is oxidized than is consumed, resulting in a negative fat balance; moreover, energy expenditure is continuously elevated $(49,97,107,108)$. The latter topics are elaborated on in the next section.

These highly controlled medium-term studies overcome possible differences that may be result from solid, semi-solid, or liquid food, timing, and macronutrient exchange, and they imply that it is possible to simultaneously assess satiety, energy expenditure, and substrate oxidation. More studies of this type of need to be executed, with different types of proteins, in overweight subjects in neutral, positive, and negative energy balances.

\section{ENERGY EXPENDITURE}

As indicated briefly above, protein intake increases energy expenditure. Potential mechanisms include the ATP required for the initial steps of metabolism, storage, and oxidation, including urea synthesis. The magnitude of the thermogenic effect is affected by the level of energy intake in relation to energy requirement in combination with the type of protein. The metabolic processes that consume the most energy are protein synthesis and gluconeogenesis. The thermogenic effect of protein is clearly illustrated by the difference between the gross energy value of $22-25 \mathrm{~kJ} / \mathrm{g}$ and the net metabolizable energy of $13 \mathrm{~kJ} / \mathrm{g}$. Effects as observed are short term as well as long term.
The four components of daily energy expenditure are (a) the sleeping metabolic rate (SMR) and the energy cost of arousal forming together the energy expenditure for maintenance or basal metabolic rate, (b) the thermic effect of food or diet-induced energy expenditure (DEE), $(c)$ the energy cost of physical activity or activity-induced energy expenditure (AEE), where SMR is usually the main component of $(d)$ average daily metabolic rate (104). Protein intake affects primarily DEE and ultimately SMR. Effects of protein intake on AEE are usually described in the opposite way: physical activity affecting protein metabolism, more specifically protein turnover. Thus, we describe below the effect of protein intake on energy expenditure for DEE, SMR, and protein turnover.

\section{Protein Intake and Diet-Induced Energy Expenditure}

The main determinant of DEE is the energy content of the food, followed by the protein fraction of the food. Diet-induced energy expenditure is related to the stimulation of energy-requiring processes during the postprandial period: the intestinal absorption of nutrients, the initial steps of their metabolism, and the storage of the absorbed but not immediately oxidized nutrients (88). As such, the amount of food ingested quantified as the energy content of the food is a determinant of DEE. The most common way to express DEE is derived from this phenomenon, the difference between energy expenditure after food consumption and basal energy expenditure, divided by the rate of nutrient energy administration. Theoretically, based on the amount of ATP required for the initial steps of metabolism and storage, the DEE is different for each nutrient. Reported DEE values for separate nutrients are $0 \%$ to $3 \%$ for fat, $5 \%$ to $10 \%$ for carbohydrate, $20 \%$ to $30 \%$ for protein (88), and $10 \%$ to $30 \%$ for alcohol (102). In healthy subjects with a mixed diet, DEE represents about $10 \%$ of the total amount of energy ingested over 24 hours. When a subject is in energy balance, where intake equals 
expenditure, DEE is $10 \%$ of daily energy expenditure (105).

One of the first studies clearly showing the effect of protein intake on DEE is a study over 24 hours in a respiration chamber (102). Healthy female volunteers were fed a high-protein/high-carbohydrate diet $(30 \%$, $60 \%$, and $10 \%$ energy from protein, carbohydrate, and fat, respectively) and a high-fat diet $(10 \%, 30 \%$, and $60 \%$ energy from protein, carbohydrate, and fat, respectively); both diets were isoenergetic, isovolumetric, composed of normal food items, and matched the organoleptic properties taste, smell, and appearance. Subjects each spent two 36-hour periods in a respiration chamber consuming both test diets in random order. Diet-induced energy expenditure was higher in all subjects while on the high-protein/high-carbohydrate $\operatorname{diet}(1295$ versus $931 \mathrm{~kJ} / \mathrm{d}$; 14.6 versus $10.5 \%$ of energy intake; $\mathrm{p}<0.02$ ), without a significant difference in other components or total 24-hour energy expenditure except for a trend toward higher energy expenditure on the high-protein/highcarbohydrate diet. In comparison with a highfat diet, a high-protein/high-carbohydrate diet induces a greater thermic response in healthy individuals. Even when the protein type was only casein, a similar difference in energy expenditure was shown (36). A recent study comparing DEE between lean and obese women after two isoenergetic meals, one rich in protein and one rich in fat, showed similar results in both groups (89). The meals were consumed as a breakfast with a total energy content of $2.03 \mathrm{MJ}$ (in a randomized crossover design with an interval of one week) and consisted of a high-protein breakfast with $102 \mathrm{~g}$ protein, $18 \mathrm{~g}$ carbohydrate, and $0 \mathrm{~g}$ fat, or a high-fat breakfast with $12 \mathrm{~g}$ protein, $20 \mathrm{~g}$ carbohydrate, and $39 \mathrm{~g}$ fat. Energy expenditure and substrate oxidation, measured for 30 minutes before breakfast and for 30 minutes every hour for a total of three hours after breakfast, showed that protein intake was associated with almost threefold-higher diet-induced energy expenditure in comparison with fat intake, with no difference between lean and obese participants.
It was concluded that over the long term, high diet-induced energy expenditure may contribute to the prevention of obesity or, vice versa, regular or frequent fat intake may contribute to the development and maintenance of obesity.

\section{Protein Intake and Sleeping Metabolic Rate}

Two studies have reported a protein-induced increase in SMR $(49,59)$. In the first study, substitution of carbohydrate with $17 \%$ to $18 \%$ of energy as either pork meat or soy protein produced 3\% higher 24-hour energy expenditure. The increase in energy expenditure was visible despite a $10 \%$ to $15 \%$ lower energy intake in the high-protein diets because of a higher satiating effect. Twenty-four-hour energy expenditure was measured on the fourth day on each diet. The observed increase in energy expenditure was visible in SMR as well as in DEE. The biological rationale behind the higher thermogenic effect of protein than of carbohydrate is explained by the fact that the body has no storage capacity to cope with high intakes of protein and therefore has to process it metabolically, which readily increases thermogenesis. The second study used a similar diet in a similar design. Subjects were fed in energy balance an adequate-protein diet, $10 \%, 60 \%$, and $30 \%$ energy from protein, carbohydrate, and fat, respectively, or a high-protein diet, 30\%, $40 \%$, and $30 \%$ energy from protein, carbohydrate, and fat, respectively, for four days in a randomized crossover design. Energy expenditure was measured on the last day in a respiration chamber. The high-protein diet, compared with the adequate-protein diet, fed at energy balance for four days increased 24-hour satiety, thermogenesis, sleeping metabolic rate, protein balance, and fat oxidation. As mentioned above, satiety is related to protein intake and incidentally to ghrelin and GLP-1 concentrations only with the high-protein diet. From the results of studies on protein intake, DEE, and SMR, it can be concluded that protein intake causes an acute increase in DEE and, when sustained 
over three days, results in an increase in SMR as well.

The ATP required for the initial steps of metabolism and oxidation including urea synthesis might explain the short-term proteininduced increase in DEE. The long-term protein-induced increase of SMR might be explained by stimulation of protein synthesis and protein turnover. Indirect evidence for the latter comes from the study of Mikkelsen et al. (59), in which animal protein in pork meat produced $2 \%$ higher 24-hour energy expenditure than did the vegetable protein in soy. The amount of protein synthesis after protein intake depends on how well the composition of essential amino acids in the dietary protein matches the optimum requirements for protein synthesis in the body. A well-balanced amino acid mixture produces a higher thermogenic response than does an amino acid mixture with a lower biological value, i.e., a different amino acid composition than is used for protein synthesis. This may explain why intake of soy protein results in less protein synthesis than does intake of animal protein.

\section{Protein Intake and Protein Turnover}

The theoretical basis of the increase in SMR may be the increase in protein turnover. Protein intake is the most important dietary determinant of whole-body protein turnover (28, $65,66,76)$. Hall developed a computational model of in vivo human energy metabolism (33). This model is based on the assumption that the protein synthesis cost is $3.60 \mathrm{~kJ} / \mathrm{g}$. Unfortunately, where both parameters are measured in the same study, there is no direct evidence for the link between the increase in SMR and an increase in protein turnover. In one study in which subjects were fed over threeweek intervals a weight-maintenance diet containing $12 \%$ of energy from protein and $21 \%$ of energy from protein, an increase in protein intake of $53 \mathrm{~g} /$ day resulted in an increase in overnight measured protein synthesis rate of $42 \mathrm{~g} /$ day (64). With the figure of protein synthesis cost of $3.60 \mathrm{~kJ} / \mathrm{g}$, this would result in an additional energy expenditure of $151 \mathrm{~kJ} / \mathrm{d}$. The two studies reporting a protein-induced change in SMR increased protein intake over four days from $10 \%$ to $30 \%$ of weight-maintenance requirement, i.e., with 104 to $108 \mathrm{~g} /$ day $(49,59)$. The resulting increase in SMR of $117 \mathrm{~kJ} / \mathrm{d}$ to $274 \mathrm{~kJ} / \mathrm{d}$ is within the expected range based on the expected increase in protein turnover and the accompanying increase in costs of protein synthesis.

Whole-body protein synthesis is affected not only by protein intake but by exercise as well, especially in the period after exercise (44). The higher protein turnover is suggested to increase the protein requirement for maintenance of nitrogen balance (27). In practice, exercise induces an increase in food intake and thus protein intake remains sufficient when it comprises a minimum of $10 \%$ of energy intake. An exercise-induced increase in protein turnover observed in endurance athletes contributed to an increase in resting metabolic rate of as much as $15 \%$ compared to sedentary subjects, after adjustment for differences in body composition $(79,100)$.

\section{PROTEIN AND AMINO ACID METABOLISM, GLUCONEOGENESIS, AND GLYCOGEN SYNTHESIS}

Daily protein intake is essential for the maintenance of protein synthesis for protein turnover, resulting in inevitable protein loss. Protein requirement is on average about one-fifth to one-tenth of the daily protein turnover of 300 gram/day in a healthy adult, depending on the type of protein. The main determinants of protein turnover are age, with children having about a threefold-higher level than elderly subjects, and protein intake with respect to type and quantity. A low protein turnover might diminish the capacity to respond successfully to stress due to illness, especially when maintained for long.

Most research focuses on the adequate amount of protein that is necessary to maintain good health, providing for healthy adults 
an estimated average requirement and recommended dietary allowance of, respectively, 0.65 and $0.83 \mathrm{~g}$ good-quality protein per $\mathrm{kg}$ body mass per day (75). Possibly, the protein requirement for good health also holds for a good protein turnover. Increasing protein intake, when energy intake is sufficient to meet energy requirement, will increase protein turnover by increasing protein synthesis and protein breakdown, not necessarily affecting protein balance (66). However, maintenance of protein balance and a net synthesis of protein theoretically are more likely at a higher protein synthesis rate as induced by increasing protein intake, thus amplifying control of net protein balance (109). Therefore, the highest rate of protein turnover is observed in rapidly growing infants.

\section{Protein Turnover and Metabolism}

Protein turnover and metabolism are strongly influenced by protein quality because protein synthesis requires adequate availability of essential amino acids. In other words, the intake of sufficient levels of these amino acids is crucial for preventing negative protein turnover. A specific appetite for essential amino acids has therefore been suggested, which is supported by the observation that rats, when fed a diet deficient in one or more essential amino acids, are able to recognize the presence of these amino acids in a range of diets with or without these amino acids $(29,90)$. Such a sensing mechanism stresses the physiological importance of maintaining an adequate rate of protein synthesis.

When ingested in surplus of postprandial protein synthesis, amino acids can readily be used as substrate for oxidation. In elderly women, increasing the amount of dietary protein from 10 to 20 energy\% results in a $63 \%$ to $95 \%$ increase in protein oxidation, depending on the protein source (68). The largest $(95 \%)$ increase in protein oxidation was observed when the predominant protein source was of animal origin, whereas this increase was only $63 \%$ when soy protein was the predominant protein source in the diet (68). Accordingly, as mentioned in the previous section,
Mikkelsen et al. (59) observed a higher dietinduced thermogenesis with pork meat than with soy protein. Differences in digestion rate of the various protein sources may contribute to differences in postprandial protein oxidation. Thus, in comparison with slowly digested protein, ingestion of rapidly digested protein results in a stronger increase in postprandial protein synthesis and amino acid oxidation $(9,17,18)$.

The metabolic efficacy of protein oxidation largely depends on the amino acid composition of the protein, since large differences exist with respect to the efficacy by which amino acids are oxidized. This is due to the large variety of carbon chains and cofactors that result from amino acid catabolism (87). For instance, the number of amino groups that undergo conversion to urea in the urea cycle (at a cost of 4 ATP) ranges from 1 for an amino acid such as proline or alanine to 3 for histidine $(60,87)$. Taking into account the stoichiometry of amino acid catabolism and urea synthesis, the calculated energy expenditure to produce ATP ranges from $153 \mathrm{~kJ} /$ ATP for cysteine to $99 \mathrm{~kJ} / A T P$ for glutamate (for glucose, this value is $91 \mathrm{~kJ} / \mathrm{ATP}$ ) (60). Thus, even though the ATP for urea production can be derived from subsequent oxidation of the remaining carbon group itself (41), the metabolic efficacy of amino acid oxidation is relatively low (for glucose and fatty acids, the calculated energy expenditure to produce ATP is 91 and $96 \mathrm{~kJ} / \mathrm{ATP}$, respectively). This relative metabolic inefficiency may contribute to the higher diet-induced energy expenditure of a high-protein meal, which, in turn, has shown to be related to subjective feelings of satiety.

\section{Gluconeogenesis}

The production of glucose through gluconeogenesis is also hypothesized to play a role in postprandial amino acid metabolism. The metabolic pathway involved in gluconeogenesis and glycogen synthesis is dependent upon the pattern of nutrient availability. The energy expenditure that it requires as well as the 
glucose homeostasis that it maintains may support the protein-induced energy expenditure. The main gluconeogenic organ is the liver, and de novo synthesis of glucose in the liver from gluconeogenic precursors including amino acids is stimulated by a high-protein diet in the fed state $(2,71)$. This hepatic gluconeogenesis may be an alternative biochemical pathway to cope with postprandial amino acid excess, i.e., when amino acids are ingested in surplus of protein synthesis, since complete oxidation of the excessive amino acids may provide more ATP than the liver could utilize (41). Hepatic gluconeogenesis could be involved in the satiating effect of protein through a modulation of glucose homeostasis and glucose signaling to the brain. When the protein content of the diet is increased, phosphoenolpyruvate carboxylase (PEPCK), which catalyzes the initial conversion of oxaloacetate to phosphoenolpyruvate is up-regulated in the fasted and in the fed state, whereas glucose 6-phosphatase (G6Pase), which catalyzes the last step of gluconeogenesis, is up-regulated in the fasted state and down-regulated in the fed state.

These data suggest that amino acids are converted into hepatic glycogen. Accordingly, hepatic glycogen stores of rats fed a high-protein diet are similar to the hepatic glycogen stores of rats fed a normal-protein diet, despite higher levels of dietary carbohydrate intake in the latter group (2). Again, the amino acid composition of the diet may influence postprandial gluconeogenesis, as not all amino acids are preferentially used for gluconeogenesis, but can also be converted into ketone bodies through ketogenesis. Thus, the amino acids threonine, isoleucine, phenylalanine, tryptophan, and tyrosine can be converted into either glucose or ketone bodies, whereas lysine and leucine are strictly ketogenic and therefore not used as a substrate for gluconeogenesis (87). Although hepatic glycogen stores as well as hepatic gluconeogenesis have been suggested to play a role in the regulation of satiety $(56,107)$, more studies are required to establish a possible relationship between elevated satiety, energy expenditure, and postprandial gluconeogenesis. The existence of intestinal gluconeogenesis and glucose portal sensing through portal vagus afferent fibers has also been hypothesized as an alternative mechanism for the elevated satiety related to a high-protein diet (61). However, the relevance and physiological significance of intestinal gluconeogenesis have been a subject of debate and need to be confirmed by other results $(31,53,98)$. Also, Previs et al. (73) conclude in their review published in this volume that there is so far no credible evidence to support the concept that glucose can be produced by the intestine. Moreover, the depressing effect of a high-protein diet on food intake is not abolished after vagotomy in the rat. Taken together, and in contrast to liver gluconeogenesis, these observations do not support both intestinal gluconeogenesis and its role through glucose portal sensing in the effect of high-protein feeding on food intake.

All in all, postabsorptive protein and amino acid metabolism is strongly influenced by protein quantity as well as protein quality (primary but also secondary structure). Protein and amino acid metabolism may be related to body weight regulation and food intake through several physiological pathways, including protein synthesis, protein oxidation, gluconeogenesis, and neurotransmitter release. Further elucidation of the role of dietary protein in weight management should, therefore, be the focus of studies on the metabolic fate of ingested amino acids in relation to energy expenditure or food intake.

\section{BODY WEIGHT AND BODY COMPOSITION}

\section{Protein Intake and Energy Intake}

The World Health Organization recommends that dietary protein should account for approximately $10 \%$ to $15 \%$ of energy when individuals are in energy balance and weight stable (110). The average daily protein intakes of various countries indicate that these recommendations reflect what is being consumed $(25,38,57,111$, 112). Protein intake may be expressed in grams 
or as percentage of energy intake (Table 1). When recommending high-protein diets, the difference between these two measures should be taken into account (Table 1). For instance, $108 \mathrm{~g}$ protein/day with a weight-maintenance diet of $12 \mathrm{MJ} / \mathrm{d}$ provides $15 \%$ of energy from protein, but the same protein intake as part of a weight-loss diet of $6 \mathrm{MJ} / \mathrm{d}$ provides $30 \%$ of energy from protein, and as part of a weightmaintenance diet after weight loss, $9 \mathrm{MJ} / \mathrm{d}$ provides $22.5 \%$ of energy from protein. To ensure that subjects are not in a negative nitrogen and protein balance during weight loss and, therefore, lose their metabolically active fatfree mass (FFM), the absolute amount of protein is of greater importance than the percentage of protein (15). Varying the protein content of a formula diet from 0 to $50 \mathrm{~g} / \mathrm{d}$ resulted in a protein loss of between 1202 to 91 grams, respectively, as measured over 28 days (85). The fat loss as a percentage of total weight loss varied from $43 \%$ with $0 \mathrm{~g} / \mathrm{d}$ protein to $79 \%$ with $50 \mathrm{~g} / \mathrm{d}$ protein (20). These results indicate that a higher protein intake changes body composition in a way that spares FFM. Similarly, a weight-maintenance diet following weight loss, sustained at an absolute amount of protein at $108 \mathrm{~g}$, will preserve FFM but lead to a reduction in fat mass (FM). Because weight maintenance after weight loss usually implies a slight weight regain, Stock's model can be applied (86). In this model, the greatest metabolic efficiency of weight gain is shown when protein intake is $10 \%$ to $15 \%$ of energy during overfeeding, and inefficiency is shown with $<5 \%$ and $>20 \%$ of energy from protein. The latter metabolic inefficiency is related to body composition. To build $1 \mathrm{~kg}$ of body weight with $60 \% \mathrm{FM}$ and $40 \%$ FFM, an additional $30 \mathrm{MJ}$ needs to be ingested, whereas to build only $1 \mathrm{~kg}$ of FFM, an additional 50 to $70 \mathrm{MJ}$ is needed $(74,86)$. Therefore, a high-protein diet may promote weight maintenance by its metabolic inefficiency because of the cost involved in sparing FFM. Therefore, recommendations of "high-protein, negativeenergy-balance diets" are based on keeping the amount of protein ingested at the same level, in general representing $10 \%$ to $15 \%$ of energy at energy balance, despite lower energy intakes (Table 1) (107).

\section{Sustained-Protein Diets for Body-Weight Loss}

In a 1999 study (80), sustained-protein diets for body-weight loss were assessed over different periods of time. A relatively high-protein diet, containing $25 \%$ of energy (implying $75 \mathrm{~g}$ of protein per day), was compared with a control diet in order to evaluate weight loss over six months when energy intake was ad libitum (80). The effect of $25 \%$ of energy intake from protein, $45 \%$ carbohydrate, and 30\% fat versus $12 \%$ protein, $58 \%$ carbohydrate, and $30 \%$ fat, on weight loss in subjects with a body mass index over $30 \mathrm{~kg} / \mathrm{m}^{2}$ was examined. Weight loss and fat loss were higher in the sustainedprotein group, 8.9 versus $5.1 \mathrm{~kg}$ and 7.6 versus $4.3 \mathrm{~kg}$, respectively, due to a lower energy intake, 5.0 MJ/d versus $6.2 \mathrm{MJ} / \mathrm{d}(\mathrm{p}<0.05)$. In a follow-up study, it was observed that after 12 months, weight loss was not significantly greater among the subjects in the high-protein group, but this group experienced a greater reduction in intra-abdominal adipose tissue (21). In addition, a favorable effect of a high-protein diet on body weight was found during six days of ad libitum feeding (22). The low-glycemicindex, low-fat, high-protein diet resulted in a spontaneous energy intake decrease of $25 \%$ in the ad libitum situation in comparison with a high-carbohydrate, low-fat diet: $8.8 \mathrm{MJ} / \mathrm{d}$ versus $11.7 \mathrm{MJ} / \mathrm{d}$, respectively. Body weight loss was $2.3 \mathrm{~kg}$ over six days compared to no weight loss in subjects on the high-carbohydrate diet. However, in comparison with an isoenergetic high-carbohydrate diet, there was no significant difference in body weight loss. Weight loss on the high-protein diet was not different from the control group, probably because of a lack of difference in energy intake.

Weigle et al. (99) confirmed this phenomenon in a controlled feeding study with 19 subjects. When the subjects receive an isoenergetic high-protein diet (protein/ fat/carbohydrate: $30 \% / 20 \% / 50 \%$ of energy), 
satiety was considerably increased, but body weight remained stable during the week the subjects consume this diet. When the subjects subsequently received the same high-protein diet ad libitum for six weeks, they consumed less of it, keeping their satiety levels at their original, usual level. During the isoenergetic highprotein diet, subjects did not lose body weight, whereas during the ad libitum high-protein diet they lost $4.9 \pm 0.5 \mathrm{~kg}$, with a decrease in FM of $3.7 \pm 0.4 \mathrm{~kg}$.

Clifton, Keogh, \& Noakes (14) concluded from their assessment of long-term effects of a high-protein weight-loss diet that a reported higher protein intake appeared to confer a weight-loss benefit; however, improvements in cardiovascular disease risk factors, biomarkers of disease, and serum vitamins and minerals were due to weight loss and not to types of diet $(14,107)$. In a study in which healthy adults $(\mathrm{n}=20)$ were assigned randomly to one of two low-fat ( $<30 \%$ energy), energy-restricted groups-high protein (30\% energy) or high carbohydrate $(60 \%$ energy)-Johnston et al. (39) observed that both diets were equally effective at reducing body weight $(-6 \%, \mathrm{p}<0.05)$ and FM $(-9 \%$ to $-11 \%, \mathrm{p}<0.05)$. However, subjects consuming the high-protein diet reported more satisfaction and less hunger in the first month of the six-week trial. Creatinine clearance was not altered by diet treatments, and nitrogen balance was more positive in subjects consuming the high-protein diet versus the high-carbohydrate diet $(3.9 \pm 1.4$ and $0.7 \pm 1.7 \mathrm{~g} \mathrm{~N} / \mathrm{d}$, respectively, $\mathrm{p}<0.05)$. They concluded that low-fat, energy-restricted diets of varying protein content $(15 \%$ to $30 \%$ energy) promoted healthful weight loss, but satisfaction with the diet was greater among those consuming the high-protein diet (39).

Furthermore, Johnstone and collegues reported on the effects of a high-protein ketogenic diet on hunger, appetite, and weight loss in obese men feeding ad libitum (40). These 17 obese men were studied in a residential trial, with food provided daily. Two highprotein (30\% of energy) ad libitum diets were provided, each for a four-week period: a low (4\%)-carbohydrate ketogenic diet and medium (35\%)-carbohydrate diet, randomized in a crossover design. With the low-carbohydrate diet, ad libitum intakes were lower, as was hunger, and weight loss was greater (6.34 versus $4.35 \mathrm{~kg}$ ). The low-carbohydrate diet induced ketosis with higher b-hydroxybutyrate concentrations. They concluded that in the short term, high-protein, low-carbohydrate ketogenic diets reduce hunger and lower food intake significantly more than do high-protein, mediumcarbohydrate nonketogenic diets (40).

These studies together suggest that bodyweight loss on a sustained, relatively highprotein diet appears to be greater under conditions of ad libitum energy intake than under conditions of isoenergetic diets. The explanation for this is that satiety is a key factor in applying high-protein diets. Under ad libitum conditions, subjects eat less from the high-protein diet than under isoenergetically fed conditions (99). Such diets contain a sufficient absolute amount of protein but lead to decreased energy intake, suggesting that in addition to metabolic effects of protein on body-weight loss, energy intake plays an important role. This is underscored by the phenomenon that under isoenergetic conditions, no statistically significant difference between body-weight losses on a high-protein or a high-carbohydrate diet is shown. Moreover, most of the studies on protein intake in relation to body-weight management show an improved body composition (i.e., an increased FFM/FM) and metabolic profile with a relatively high-protein diet. The relatively high-protein negative-energy-balance diets all consist of $25 \%$ to $30 \%$ of energy from protein and imply a sustained normal protein intake in grams while energy intake is decreased (Table 1).

\section{Sustained Relatively High-Protein Diets for Body-Weight Maintenance}

Studies suggest that high-protein diets can promote weight maintenance. For example, overweight to moderately obese men and women who lose weight $(7.5 \pm 2.0 \%$ body-weight loss 
over four weeks) and consume $18 \%$ of energy intake as protein thereafter regain less weight $(1 \mathrm{~kg})$ after three months compared to those consuming $15 \%$ of energy as protein (weight regain $2 \mathrm{~kg}$ ) (6). This is not a consequence of possible differences in dietary restraint or in physical activity between the high-protein and the control group, indicating a metabolic effect of protein (106). The composition of the body mass regained is more favorable in the higherprotein group (i.e., no regain of FM, but only of FFM, resulting in a lower percentage body fat) (106). Energy efficiency ( $\mathrm{kg}$ body-mass regain/energy intake) is significantly lower in the higher-protein group. The observations with respect to energy efficiency during weight regain are comparable to the "stock hypothesis" described for weight gain (86).

Using a design similar to that of the previously mentioned weight-maintenance study by Westerterp-Plantenga et al. (106), Lejeune and colleagues (48) demonstrated a weight regain of $0.8 \mathrm{~kg}$ (high-protein group) versus $3.0 \mathrm{~kg}$ (control group) $(\mathrm{p}<0.05)$ after six months on a weight-maintenance diet. During follow-up one year after the weight-loss program, these figures were $1.0 \mathrm{~kg}$ versus $3.9 \mathrm{~kg}(\mathrm{p}<0.05)$. Thus, evidence shows that a relatively highprotein intake sustains weight maintenance by (a) favoring regain of FFM at the cost of FM at a similar physical activity level, (b) reducing the energy efficiency with respect to the body mass regained, and $(c)$ increasing satiety.

Similar observations were reported by Lacroix et al. (46) from a long-term relatively high-protein diet that markedly reduced adipose tissue without major side effects in Wistar male rats.

There is a need to distinguish absolute protein intake and proportionate protein intake in summarizing the role of dietary protein in body weight loss and body weight maintenance thereafter. Absolute protein intake seems to be more important than is the proportion of protein in the diet. When energy intake is reduced, protein intake should be sustained, so that expressed in grams/day the protein content is normal. Therefore, high-protein negative- energy-balance diets should keep the grams of protein ingested at the same level, i.e., representing $10 \%$ to $15 \%$ of energy at energy balance, despite lower energy intakes (Table 1). Protein influences body weight regulation via its effects on satiety, thermogenesis, energy efficiency, and body composition. These aspects are partly related to each other. Under conditions of slight body-weight regain, while aiming for weight maintenance, a sustained-protein diet shows reduced energy efficiency related to the body composition of the body weight regained, i.e., in favor of FFM. Here, the main issue is that building FFM requires, on average, an additional energy ingestion of $52 \mathrm{MJ} / \mathrm{kg}$ body mass built, whereas building a normal proportion of FM and FFM takes $30 \mathrm{MJ} / \mathrm{kg}$ body mass built. During body-weight loss as well as during weight maintenance thereafter, a highprotein diet preserves or increases FFM, reduces FM, and improves the metabolic profile.

\section{POTENTIAL RISK OF HIGH-PROTEIN DIETS}

Diets absolutely high in protein may promote renal damage via excretion of nitrogenous waste products generated from protein metabolism, thereby increasing glomerular pressure and hyperfiltration (98). However, long-term consumption of a high-protein diet in rats had no deleterious effects on renal and hepatic functions (55), and long-term daily protein intakes under $2.8 \mathrm{~g} / \mathrm{kg}$ body weight were shown to have no negative effects on renal function in athletes (81). In subjects without renal impairment, changes in dietary protein intake caused adaptive alterations in renal size and function without adverse effects (100). In fact, the changes in renal function (induced by high dietary protein) are a normal adaptive mechanism (54) and there is little evidence that high-protein diets pose a serious risk to kidney function in healthy populations (34).

However, long-term consumption of highprotein diets in the absolute sense, i.e., in grams, may have adverse effects on the kidney, e.g., on blood pressure. Amino acids 
involved in gluconeogenesis and/or ureagenesis have a blood pressure-lowering effect, whereas acidifying amino acids have a blood pressureraising effect $(3,26,37,72)$. Subjects with subclinical renal injury, including elderly subjects, subjects with low renal functional mass such as renal transplant recipients, and subjects with obesity-related conditions, such as metabolic syndrome and type 2 diabetes, are more susceptible than others to the blood pressure-raising effects $(3,26,37,72)$. In particular, sulfurcontaining amino acids cause a blood pressureraising effect by maintaining acid-base homeostasis through excretion of the excess acid load by the kidneys $(26,37)$. When kidneys compensate by increased excretion of ammonia, through stimulated ammoniagenesis with glutamine as substrate, an effect on blood pressure occurs, which leads to loss of nephron mass (3, $26,37,72)$. The established synergy between obesity and low nephron number on induction of high blood pressure identifies subjects with obesity, metabolic syndrome, and type 2 diabetes as particularly susceptible groups $(3,13)$. So, in more susceptible groups such as diabetics and patients with renal disease, the effects of high protein intake are less clear $(23,34)$. In a study of patients with type II diabetes, restriction of protein intake from $1.2 \mathrm{~g} / \mathrm{kg}$ to $0.9 \mathrm{~g} / \mathrm{kg}$, especially of animal protein, appeared to beneficially influence albuminuria, a marker for the onset of renal disorders (71). However, it must be noted that renal functions in diabetes patients are often diminished; therefore, these results should not be generalized to healthy individuals.

Opponents of high-protein diets are also concerned about the interference of high protein intake with calcium homeostasis. Indeed, several short-term studies demonstrate increased renal calcium excretion and negative calcium balance at intakes of $2.0 \mathrm{~g} / \mathrm{kg}$ protein daily when compared with control diets containing $0.7-1.0 \mathrm{~g} / \mathrm{kg}$ daily (23). Explanations for these effects are mainly focused on the acid load generated by high-protein diets. This large acid load would be partially buffered by bone, which would result in bone resorption and hypercal- ciuria unless buffered by the consumption of alkali-rich foods such as fruits and vegetables (5). Furthermore, the effect of a high-protein diet and a moderate-protein $\operatorname{diet}(2.1 \mathrm{~g} / \mathrm{kg}$ and $1.0 \mathrm{~g} / \mathrm{kg}$, respectively) on bone resorption was tested in a study with calcium isotopes (43). An increase of urinary calcium excretion in the high-protein group was explained by increased intestinal calcium absorption with no contribution from bone resorption. Therefore, it was concluded that there were no protein-induced effects on net bone balance (43). Despite the hypercalciuretic effects of dietary protein, an increase of dietary protein from $12 \%(1.2 \mathrm{~g} / \mathrm{kg})$ to $21 \%(2.1 \mathrm{~g} / \mathrm{kg})$ did not have a negative effect on calcium balance in young adults and elderly persons (67). Some studies even report positive effects of protein intake. A recent review analyzed clinically large prospective epidemiologic studies and concluded that relatively high-protein intake is associated with increased bone mineral mass and reduced incidence of osteoporotic fracture (10). Furthermore, during weight loss, nitrogen intake seems to have a positive effect on calcium balance and consequent preservation of bone mineral content $(82,103)$.

\section{HYPOTHESES TO BE ASSESSED}

The role of dietary protein in weight loss and weight maintenance encompasses the influence of dietary protein on the crucial targets for body-weight regulation, namely effects on satiety, thermogenesis, energy efficiency, and body composition. These aspects are partly related to each other. Under conditions of slight bodyweight regain while aiming for weight maintenance, a sustained-protein diet shows reduced energy efficiency related to the body composition of the body weight regained, i.e., in favor of FFM. Here, the main issue is that building FFM requires, on average, an additional energy ingestion of $52 \mathrm{MJ} / \mathrm{kg}$ body mass built, whereas building a normal proportion of FM and FFM takes $30 \mathrm{MJ} / \mathrm{kg}$ body mass built. During bodyweight loss as well as during weight maintenance thereafter, a high-protein diet preserves or increases FFM, reduces FM, and improves 
the metabolic profile. The way dietary protein triggers this FFM-sparing effect deserves further research in (a) energy balance to assess its contribution to prevention of weight (re)gain, as well as in (b) negative energy balance to assess preservation of FFM while losing FM. The protein synthesis observed during short-term experiments cannot be straightforwardly extrapolated to the long term; therefore, experiments of four to six weeks are needed to assess the relationship between protein synthesis and sparing FFM under diets relatively high in protein.

Protein-induced satiety appears to be mainly due to oxidation of amino acids fed in excess, especially with diets with incomplete proteins, and perhaps due to gluconeogenesis restoring glucose homeostasis. This topic deserves closer assessment in a quantitative way, using different dosages and different types of incomplete proteins, as well as in a qualitative way, using tracer techniques to study the metabolic fate of the ingested amino acids.

Protein-induced energy expenditure appears to be mainly due to protein synthesis; therefore, high-quality proteins, i.e., complete proteins having all essential amino acids, show larger increases in energy expenditure than do lower-quality proteins.

With respect to adverse effects, no proteininduced effects on net bone balance or on calcium balance in young adults and elderly persons have been observed. Dietary protein even increases bone mineral mass and reduces incidence of osteoporotic fracture. During weight loss, nitrogen intake has a positive effect on calcium balance and consequent preservation of bone mineral content.

Sulphur-containing amino acids cause a blood pressure-raising effect by maintaining acid-base homeostasis through excretion of the excess acid load by the kidneys, ultimately leading to loss of nephron mass. The established synergy between obesity and low nephron number on induction of high blood pressure identifies subjects with obesity, metabolic syndrome, and type 2 diabetes as particularly susceptible groups. This area of research deserves further attention, with a focus on the roles of different proteins.

\section{CONCLUSIONS}

Weight loss and weight maintenance require sustained satiety, sustained energy expenditure, and sparing fat free mass while subjects are in negative energy balance. Protein-induced sustained satiety in negative energy balance occurs mainly by oxidation of excessively ingested amino acids. Protein-induced sustained-energy expenditure occurs depending on the type of protein, mainly by net protein synthesis, or by gluconeogenesis. The possible long-term relationship between net protein synthesis and sparing fat free mass remains to be elucidated.

\section{DISCLOSURE STATEMENT}

The authors are not aware of any biases that might be perceived as affecting the objectivity of this review.

\section{ACKNOWLEDGMENTS}

Part of this review is an update of Stijn Soenen and Margriet S. Westerterp-Plantenga, 2008, Proteins and satiety: implications for weight management, Current Opinion in Clinical Nutrition and Metabolic Care 11:747-51 (with permission) (85).

\section{LITERATURE CITED}

1. D’Andrea G, Ostuzzi R, Bolner A, Francesconi F, Musco F, et al. 2008. Study of tyrosine metabolism in eating disorders. Possible correlation with migraine. Neurol. Sci. 29:S88-92 
2. Azzout-Marniche D, Gaudichon C, Blouet C, Bos C, Mathe V, et al. 2007. Liver glyconeogenesis: a pathway to cope with postprandial amino acid excess in high-protein fed rats? Am. F. Physiol. Regul. Integr. Comp. Physiol. 292(4):R1400-7

3. Bagby SP. 2007. Maternal nutrition, low nephron number, and hypertension in later life: pathways of nutritional programming. F. Nutr. 137:1066-72

4. Batterham RL, Heffron H, Kapoor S, Chivers JE, Chandarana K, et al. 2006. Critical role for peptide $\mathrm{YY}$ in protein-mediated satiation and body-weight regulation. Cell Metab. 4:223-33

5. Barzel US, Massey LK. 1998. Excess dietary protein can adversely affect bone. 7 . Nutr. 128:1051-53

6. Bellissimo N, Desantadina MV, Pencharz PB, Berall GB, Thomas SG, et al. 2008. A comparison of shortterm appetite and energy intakes in normal weight and obese boys following glucose and whey-protein drinks. Int. F. Obes. 32:362-71

7. Bertenshaw EJ, Lluch A, Yeomans MR. 2008. Satiating effects of protein but not carbohydrate consumed in a between meal beverage context. Physiol. Behav. 93:427-36

8. Beulens JW, Bindels JG, de Graaf C, Alles MS, Wouters-Wesseling W. 2004. Alpha-lactalbumin combined with a regular diet increases plasma Trp-LNAA ratio. Physiol. Behav. 81(4):585-93

9. Boirie Y, Dangin M, Gachon P, Vasson MP, Maubois JL, Beaufrere B. 1997. Slow and fast dietary proteins differently modulate postprandial protein accretion. Proc. Natl. Acad. Sci. USA 94:14930-35

10. Bonjour JP. 2005. Dietary protein: an essential nutrient for bone health. 7. Am. Coll. Nutr. 24:526-36S

11. Bowen J, Noakes M, Clifton PM. 2006. Energy intake, ghrelin, and cholecystokinin after different carbohydrate and protein preloads in overweight men. 7. Clin. Endocrinol. Metab. 91:1477-83

12. Bowen J, Noakes M, Clifton PM. 2006. Appetite regulatory hormone responses to various dietary proteins differ by body mass index status despite similar reductions in ad libitum energy intake. 7 . Clin. Endocrinol. Metab. 91:2913-19

13. Burton Freeman BM. 2008. Glycomacropeptide (GMP) is not critical to whey-induced satiety, but may have a unique role in energy intake regulation through cholecystokinin (CCK). Physiol. Behav. 93:379-87

14. Clifton PM, Keogh JB, Noakes M. 2008. Long-term effects of a high-protein weight-loss diet. Am. 7 . Clin. Nutr. 87:23-29

15. Contaldo F, Di Biase G, Scalfi L, Presta E, Mancini M. 1980. Protein-sparing modified fast in the treatment of severe obesity: weight loss and nitrogen balance data. Int. F. Obes. 4(3):189-96

16. Cota D, Proulx K, Smith KA, Kozma SC, Thomas G, et al. 2006. Hypothalamic mTOR signaling regulates food intake. Science 312:927-30

17. Dangin M, Boirie Y, Garcia-Rodenas C, Gachon P, Fauquant J, et al. 2001. The digestion rate of protein is an independent regulating factor of postprandial protein retention. Am. 7. Physiol. Endocrinol. Metab. 280(2):E340-48

18. Dangin M, Boirie Y, Guillet C, Beaufrere B. 2002. Influence of the protein digestion rate on protein turnover in young and elderly subjects. F. Nutr. 132(10):3228-33S

19. Diepvens K, Haberer D, Westerterp-Plantenga MS. 2008. Different proteins and biopeptides differently affect satiety and anorexigenic/orexigenic hormones in healthy humans. Int. 7. Obes. 32:10-18

20. Ditschuneit HH. 1984. Ergebnisse ambulante Adipositastherapie mit verschiedenen proteinereichen Diaeten. In Ergebnisse der Adipositasforschung, ed. H Ditschuneit, JG Wechsler, pp. 171-78. Erlangen, Germany: perimed-Fachbuch-Verlagsgesellschaft

21. Due A, Toubro S, Skov AR, Astrup A. 2004. Effect of normal-fat diets, either medium or high in protein, on body weight in overweight subjects: a randomised 1-year trial. Int. F. Obes. 28:1283-90

22. Dumesnil JG, Turgeon J, Tremblay A. 2001. Effect of a low-glycemic index-low-fat-high-protein diet on the atherogenic metabolic risk profile of abdominally obese men. Br. F. Nutr. 86:557-68

23. Eisenstein J, Roberts SB, Dallal G, Saltzman E. 2002. High-protein weight-loss diets: Are they safe and do they work? A review of the experimental and epidemiologic data. Nutr. Rev. 60:189-200

24. Faipoux R, Tomé D, Gougis S, Darcel N, Fromentin G. 2008. Proteins activate satiety-related neuronal pathways in the brainstem and hypothalamus of rats. F. Nutr: 38:1172-78

25. FAO Statistics Division. http://www.dietaryfiberfood.com/protein-requirement.php

26. Frassetto LA, Morris RC Jr, Sebastian A. 2006. A practical approach to the balance between acid production and renal acid excretion in humans. F. Nephrol. 19:S33-40 
27. Gaine PC, Pikosky A. Martin WF, Bolster DR, Maresh CM, et al. 2006. Level of dietary protein impacts whole body protein turnover in trained males at rest. Metabolism 55:501-7

28. Garlick PJ, McNurlan MA, Ballmer PE. 1991. Influence of dietary protein intake on whole-body protein turnover in humans. Diabetes Care 14:1189-98

29. Gietzen DW, Hao S, Anthony TG. 2007. Mechanisms of food intake repression in indispensable amino acid deficiency. Annu. Rev. Nutr. 27:63-78

30. Goto K, Kasaoka S, Takizawa M, Ogawa M, Tsuchiya T, Nakajima S. 2007. Bitter taste and blood glucose are not involved in the suppressive effect of dietary histidine on food intake. Neurosci. Lett. 420(2):106-9

31. Habold C, Foltzer-Jourdainne C, Le Maho Y, Lignot J-H, Oudart H. 2005. Intestinal gluconeogenesis and glucose transport according to body fuel availability in rats. F. Physiol. 566:575-86

32. Halford JC, Harrold JA, Boyland EJ, Lawton CL, Blundell JE. 2007. Serotonergic drugs: effects on appetite expression and use for the treatment of obesity. Drugs 67(1):27-55

33. Hall KD. 2006. Computational model of in vivo human energy metabolism during semistarvation and refeeding. Am. 7. Physiol. Endocrinol. Metab. 291:E23-37

34. Halton TL, Hu FB. 2004. The effects of high protein diets on thermogenesis, satiety and weight loss: a critical review. F. Am. Coll. Nutr. 23(5):373-85

35. Harper A, James A, Flint A, Astrup A. 2007. Increased satiety after intake of a chocolate milk drink compared with a carbonated beverage, but no difference in subsequent ad libitum lunch intake. $B r . \mathcal{F}$. Nutr: 97:579-83

36. Hochstenbach-Waelen A, Veldhorst MA, Nieuwenhuizen AG, Westerterp-Plantenga MS, Westerterp KR. 2009. Comparison of 2 diets with either $25 \%$ or $10 \%$ of energy as casein on energy expenditure, substrate balance, and appetite profile. Am. F. Clin. Nutr. 89:831-38

37. Hoy WE, Hughson MD, Bertram JF, Douglas-Denton R, Amann K. 2005. Nephron number, hypertension, renal disease, and renal failure. 7. Am. Soc. Nephrol. 16:2557-64

38. Hulshof KFAM, Ocke MC, van Rossum CTM, Buurma-Rethans EJM, Brants HAM, Drijvers JJMM. 2004. Results of the Food Consumption Survey 2003. RIVM/TNO, Bilthoven/Zeist, The Netherlands

39. Johnston CS, Tjonn SL, Swan PD. 2004. High-protein, low-fat diets are effective for weight loss and favorably alter biomarkers in healthy adults. F. Nutr: 134:586-91

40. Johnstone AM, Horgan GW, Murison SD, Bremner DM, Lobley GE. 2008. Effects of a high-protein ketogenic diet on hunger, appetite, and weight loss in obese men feeding ad libitum. Am. F. Clin. Nutr. $87: 44-55$

41. Jungas RL, Halperin ML, Brosnan JT. 1992. Quantitative analysis of amino acid oxidation and related gluconeogenesis in humans. Physiol. Rev. 72:419-48

42. Kasaoka S, Tsuboyama-Kasaoka N, Kawahara Y, Inoue S, Tsuji M, et al. 2004. Histidine supplementation suppresses food intake and fat accumulation in rats. Nutrition 20(11-12):991-96

43. Kerstetter JE, O'Brien KO, Caseria DM, Wall DE, Insogna KL. 2005. The impact of dietary protein on calcium absorption and kinetic measures of bone turnover in women. F. Clin. Endocrinol. Metab. 90:26-31

44. Koopman R, Saris WH, Wagenmakers AJ, van Loon LJ. 2007. Nutritional interventions to promote post-exercise muscle protein synthesis. Sports Med. 37:895-906

45. Koren MS, Purnell JQ, Breen PA, Matthys CC, Callahan HS, et al. 2007. Changes in plasma amino acid levels do not predict satiety and weight loss on diets with modified macronutrient composition. Ann. Nutr. Metab. 51:182-87

46. Lacroix M, Gaudichon C, Martin A, Morens C, Mathe V, et al. 2004. A long-term high-protein diet markedly reduces adipose tissue without major side effects in Wistar male rats. Am. F. Physiol. Regul. Integr: Comp. Physiol. 287(4):R934-42

47. Leibowitz SF, Alexander JT. 1998. Hypothalamic serotonin in control of eating behavior, meal size, and body weight. Biol. Psychiatry 44(9):851-64

48. Lejeune MPGM, Kovacs EMR, Westerterp-Plantenga MS. 2005. Additional protein intake limits weight regain after weight loss in humans. Br. F. Nutr. 93:281-89

49. Lejeune MPGM, Westerterp KR, Adam TC, Luscombe-Marsh ND, Westerterp-Plantenga MS. 2006. Ghrelin and glucagon-like peptide 1 concentrations, 24-h satiety, and energy and substrate metabolism during a high-protein diet and measured in a respiration chamber. Am. F. Clin. Nutr. 83:89-94 
50. Luhovyy BL, Akhavan T, Anderson GH. 2007. Whey proteins in the regulation of food intake and satiety. F. Am. Coll. Nutr. 26:704-12S

51. Markus CR, Olivier B, de Haan EHF. 2002. Whey protein rich in alpha-lactalbumin increases the ratio of plasma tryptophan to the sum of the other large neutral amino acids and improves cognitive performance in stress-vulnerable subjects. Am. F. Clin. Nutr. 75(6):1051-56

52. Markus CR, Olivier B, Panhuysen GE, Van Der Gugten J, Alles MS, et al. 2000. The bovine protein alpha-lactalbumin increases the plasma ratio of tryptophan to the other large neutral amino acids, and in vulnerable subjects raises brain serotonin activity, reduces cortisol concentration, and improves mood under stress. Am. F. Clin. Nutr. 71(6):1536-44

53. Martin G, Ferrier B, Conjard A, Martin M, Nazaret R, et al. 2007. Glutamine gluconeogenesis in the small intestine of $72 \mathrm{~h}$-fasted adult rats is undetectable. Biochem. 7. 401:465-73

54. Martin WF, Armstrong LE, Rodriguez NR. 2005. Dietary protein intake and renal function. Nutr. Metab. 2:25

55. Martin WF, Cerundolo LH, Pikosky MA, Gaine PC, Maresh CM, et al. 2006. Effects of dietary protein intake on indexes of hydration. 7. Am. Diet. Assoc. 106:587-89

56. McCarty MF. 1994. Promotion of hepatic lipid oxidation and gluconeogenesis as a strategy for appetite control. Med. Hypotheses 42(4):215-25

57. McLennan W, Podger A. 1998. National Nutrition Survey: Nutrient Intakes and Physical Measurements. Canberra: Australian Bureau of Statistics

58. Mellinkoff SM. 1956. Relationship between serum amino acid concentration and fluctuations in appetite. 7. Appl. Physiol. 8:535-38

59. Mikkelsen PB, Toubro S, Astrup A. 2000. Effect of fat-reduced diets on 24-h energy expenditure: comparisons between animal protein, vegetable protein and carbohydrate. Am. F. Clin. Nutr. 72:1135-41

60. van Milgen J. 2002. Modeling biochemical aspects of energy metabolism in mammals. 7. Nutr. 132(10):3195-202

61. Mithieux G, Misery P, Magnan C, Pillot B, Gautier-Stein A, et al. 2005. Portal sensing of intestinal gluconeogenesis is a mechanistic link in the diminution of food intake induced by diet protein. Cell Metab. 2:321-29

62. Morimoto T, Yamamoto Y, Yamatodani A. 2001. Brain histamine and feeding behavior. Behav. Brain Res. 124(2):145-50

63. Morrison CD, Xi X, White CL, Ye J, Martin RJ. 2007. Amino acids inhibit Agrp gene expression via an mTOR-dependent mechanism. Am. F. Physiol. Endocrinol. Metab. 293:E165-71

64. Nieuwenhuizen AG, Hochstenbach-Waelen A, Veldhorst M, Westerterp KR, Engelen MPKJ, et al. 2008. Acute effects of breakfasts containing alpha-lactalbumin, or gelatin with or without added tryptophan, on hunger, "satiety" hormones and amino acid profiles. Br. F. Nutr. 19:1-8

65. Pannemans DL, Halliday D, Westerterp KR. 1995. Whole-body protein turnover in elderly men and women: responses to two protein intakes. Am. 7. Clin. Nutr. 61:33-38

66. Pannemans DL, Halliday D, Westerterp KR, Kester AD. 1995. Effect of variable protein intake on whole-body protein turnover in young men and women. Am. 7. Clin. Nutr. 61:69-74

67. Pannemans DL, Schaafsma G, Westerterp KR. 1997. Calcium excretion, apparent calcium absorption and calcium balance in young and elderly subjects: influence of protein intake. Br. F. Nutr. 77(5):721-29

68. Pannemans DL, Wagenmakers AJ, Westerterp KR, Schaafsma G, Halliday D. 1998. Effect of protein source and quantity on protein metabolism in elderly women. Am. 7. Clin. Nutr. 68:1228-35

69. Pichon L, Potier M, Tome D, Mikogami T, Laplaize B, et al. 2008. High-protein diets containing different milk protein fractions differently influence food intake and adiposity in rat. Br. 7. Nutr. 99:73948

70. Pi-Sunyer FX. 1993. Medical hazards of obesity. Ann. Intern. Med. 119:655-60

71. Pijls LT, de Vries H, Donker AJ, van Eijk JT. 1999. The effect of protein restriction on albuminuria in patients with type 2 diabetes mellitus: a randomized trial. Nephrol. Dial. Transplant. 114:1445-53

72. Praga M. 2005. Synergy of low nephron number and obesity: a new focus on hyperfiltration nephropathy. Nephrol. Dial. Transplant. 20:2594-97

73. Previs SF, Brunengraber DZ, Brunengraber H. 2009. Is there glucose production outsider of the liver and kidney? Annu. Rev. Nutr. 29:43-57 
74. Pullar JD, Webster AJF. 1977. The energy cost of fat and protein disposition in the rat. Br. 7 . Nutr. 37:355-63

75. Rand WM, Pellett PL, Young VR. 2003. Meta-analysis of nitrogen balance studies for estimating protein requirements in healthy adults. Am. 7. Clin. Nutr. 77(1):109-27

76. Robinson SM, Jaccard C, Persaud C, Jackson AA, Jequier E, et al. 1990. Protein turnover and thermogenesis in response to high-protein and high-carbohydrate feeding in men. Am. F. Clin. Nutr. 52:72-80

77. Ropelle ER, Pauli JR, Fernandes MF, Rocco SA, Marin RM, et al. 2008. A central role for neuronal AMP-activated protein kinase (AMPK) and mammalian target of rapamycin (mTOR) in high-protein diet-induced weight loss. Diabetes 57:594-605

78. Seidell JC. 1995. Obesity in Europe. Obes. Res. 3:89-93S

79. Sjödin AM, Forslund AH, Westerterp KR, Andersson AB, Forslund JM, et al. 1996. The influence of physical activity on BMR. Med. Sci. Sports Exerc. 28:85-91

80. Skov AR, Toubro S, Ronn B, Astrup A. 1999. Randomized trial on protein vs carbohydrate in ad libitum fat reduced diet for the treatment of obesity. Int. 7. Obes. 23:528-36

81. Skov AR, Haulrik N, Toubro S, Molgaard C, Astrup A. 2002. Effect of protein intake on bone mineralization during weight loss: a 6-month trial. Obes. Res. 10:432-38

82. Skov AR, Toubro S, Bulow J, Krabbe K, Parving HH, Astrup A. 1999. Changes in renal function during weight loss induced by high- vs low-protein low-fat diets in overweight subjects. Int. F. Obes. Relat. Metab. Disord. 23(11):1170-77

83. Smeets AJ, Soenen S, Luscombe-Marsh ND, Ueland Ø, Westerterp-Plantenga MS. 2008. Energy expenditure, satiety, and plasma ghrelin, glucagon-like peptide 1, and peptide tyrosine-tyrosine concentrations following a single high-protein lunch. F. Nutr. 138:698-702

84. Soenen S, Westerterp-Plantenga MS. 2007. No differences in satiety or energy intake after high-fructose corn syrup, sucrose, or milk preloads. Am. 7. Clin. Nutr. 86:1586-94

85. Soenen S, Westerterp-Plantenga MS. 2008. Proteins and satiety: implications for weight management. Curr. Opin. Clin. Nutr. Metab. Care 11:747-51

86. Stock MJ. 1999. Gluttony and thermogenesis revisited. Int. F. Obes. 23:1105-17

87. Stryer L. 1988. Biochemistry. New York: Freeman

88. Tappy L. 1996. Thermic effect of food and sympathetic nervous system activity in humans. Reprod. Nutr. Dev. 36:391-97

89. Tentolouris N, Pavlatos S, Kokkinos A, Perrea D, Pagoni S, et al. 2008. Diet-induced thermogenesis and substrate oxidation are not different between lean and obese women after two different isocaloric meals, one rich in protein and one rich in fat. Metabolism 57:313-20

90. Tome D. 2004. Protein, amino acids and the control of food intake. Br. F. Nutr: 92:S27-30

91. Toornvliet AC, Pijl H, Hopman E, Elte-de Wever BM, Meinders AE. 1996. Serotoninergic drug-induced weight loss in carbohydrate-craving obese patients. Int. F. Obes. Relat. Metab. Disord. 20(10):917-20

92. Veldhorst MAB, Nieuwenhuizen A, Hochstenbach-Waelen A, Westerterp KR, Engelen MP, et al. 2009. Effects of complete whey-protein breakfasts versus whey without GMP-breakfasts on energy intake and satiety. Appetite 52:388-95

93. Veldhorst MAB, Nieuwenhuizen A, Hochstenbach-Waelen A, Westerterp KR, Engelen MP, et al. 2009. Comparison of the effects of a high- and normal-casein breakfast on satiety, "satiety" hormones, plasma amino acids and subsequent energy intake. Br. F. Nutr. 101(2):295-303

94. Veldhorst MAB, Nieuwenhuizen A, Hochstenbach-Waelen A, Westerterp KR, Engelen M, et al. 2009. Effects of high and normal soyprotein breakfasts on satiety and subsequent energy intake, including amino acid and "satiety" hormone responses. Eur. 7 . Nutr. 48:92-100

95. Veldhorst MAB, Nieuwenhuizen A, Hochstenbach-Waelen A, van Vught A, Westerterp K, et al. 2009. Dose-dependent satiating effect of whey relative to casein or soy. Physiol. Behav. 96(4-5):675-82

96. Veldhorst MAB, Nieuwenhuizen A, Hochstenbach-Waelen A, Westerterp KR, Engelen MP, et al. 2009. A breakfast with alpha-lactalbumin, gelatin, or gelatin+TRP lowers energy intake at lunch compared with a breakfast with casein, soy, whey, or whey-GMP. Clin. Nutr. Jan. 29 [Epub ahead of print]

97. Veldhorst MAB, Smeets A, Soenen S, Hochstenbach-Waelen A, Hursel R, et al. 2008. Protein-induced satiety: effects and mechanisms of different proteins. Physiol. Behav. 94:300-7 
98. Watford M. 2005. Is the small intestine a gluconeogenic organ? Nutr. Rev. 63:356-60

99. Weigle DS, Breen PA, Matthys CC, Callahan HS, Meeuws KE, et al. 2005. A high protein diet induces sustained reductions in appetite, ad libitum caloric intake, and body weight despite compensatory changes in diurnal plasma leptin and ghrelin concentrations. Am. F. Clin. Nutr. 82:41-48

100. Welle S, Nair KS. 1990. Relationship of resting metabolic rate to body composition and protein turnover. Am. 7. Physiol. 258:E990-98

101. Wellman PJ. 2005. Modulation of eating by central catecholamine systems. Curr. Drug Targets 6(2):19199

102. Westerterp KR, Wilson SAJ, Rolland A. 1999. Diet-induced thermogenesis measured over $24 \mathrm{~h}$ in a respiration chamber: effect of diet composition. Int. F. Obes. 23:287-92

103. Westerterp KR. 2002. Weight loss and bone mineral content. Obes. Res. 10:559

104. Westerterp KR. 2003. Energy metabolism and body composition: general principles. Eur. Resp. Monogr. 24:1-10

105. Westerterp KR. 2004. Diet-induced thermogenesis. Nutr. Metab. 1:1-5

106. Westerterp-Plantenga MS, Lejeune MPGM, Nijs I, van Ooijen M, Kovacs EMR. 2004. High protein intake sustains weight maintenance after body weight loss in humans. Int. 7. Obes. 28:57-64

107. Westerterp-Plantenga MS, Natalie Luscombe-Marsh N, Lejeune MPGM, Diepvens K, Nieuwenhuizen A, et al. 2006. Dietary protein, metabolism, and body-weight regulation: dose-response effects. Int. $\mathcal{F}$. Obes. 30:S16-23

108. Westerterp-Plantenga MS, Lejeune MPGM, Smeets AJPG, Luscombe-Marsh ND. 2009. Sex differences in energy homeostasis following a diet relatively high in protein exchanged with carbohydrate, assessed in a respiration chamber in humans. Physiol. Behav. March 21 [Epub ahead of print]

109. Wolfe RR. 1992. Radioactive and Stable Isotope Tracers in Biomedicine: Principles and Practice of Kinetic Analysis. New York: Wiley-Liss

110. World Health Organ. Tech. Rep. Ser. 2000. Obesity: preventing and managing the global epidemic. Report of WHO consultation. 894:i-xii, 1-253

111. World Health Organ. 2000. Nutrition Profile of the WHO South-East Asia Region. New Delhi: WHO Regional Office for South-East Asia

112. Wright JD, Kennedy-Stephenson J, Wang CY, McDowell MA, Johnson CL. 2004. Trends in intake of energy and macronutrients-United States, 1971-2000. FAMA 291:1193-94

113. Wurtman RJ, Wurtman JJ. 1988. Do carbohydrates affect food intake via neurotransmitter activity? Appetite 11:42-47

114. Zhang Y, Guo K, LeBlanc RE, Loh D, Schwartz GJ, Yu Y-H. 2007. Increasing dietary leucine intake reduces diet-induced obesity and improves glucose and cholesterol metabolism in mice via multimechanisms. Diabetes 56:1647-54 
迹

\section{Contents}

Annual Review of Nutrition

Volume 29, 2009

From Tryptophan to Hydroxytryptophan: Reflections on a Busy Life

Hans Fisher

Dietary Protein, Weight Loss, and Weight Maintenance

M.S. Westerterp-Plantenga, A. Nieuwenbuizen, D. Tomé, S. Soenen, and K.R. Westerterp .....

Is There Glucose Production Outside of the Liver and Kidney?

Stephen F. Previs, Daniel Z. Brunengraber, and Henri Brunengraber

Use of Phosphatide Precursors to Promote Synaptogenesis

Richard 7. Wurtman, Mebmet Cansev, H. Ismail Ulus, and Toshimasa Sakamoto

Roles for Vitamin K Beyond Coagulation

Sarah L. Booth .....

Vitamin D Gene Pathway Polymorphisms and Risk of Colorectal, Breast, and Prostate Cancer Marjorie L. McCullough, Roberd M. Bostick, and Tinisha L. Mayo

Functional Significance of Zinc-Related Signaling Pathways in Immune Cells Hajo Haase and Lothar Rink

Mammalian Zinc Transporters: Nutritional and Physiologic Regulation Louis A. Lichten and Robert 7. Cousins

Sialic Acid is an Essential Nutrient for Brain Development and Cognition

Bing Wang

Management of the Metabolic Syndrome and Type 2 Diabetes

Through Lifestyle Modification

Faidon Magkos, Mary Yannakoulia, Fean L. Chan, and Christos S. Mantzoros

The Nutritional Significance of Lipids Rafts

Parveen Yaqoob

Genetic Variation and Effects on Human Eating Behavior

Mariken de Krom, Florianne Bauer, David Collier, R.A.H. Adan, and Susanne E. la Fleur 
Is There a Fatty Acid Taste?

Richard D. Mattes

Nutritional Systems Biology: Definitions and Approaches

Gianni Panagiotou and fens Nielsen

Navigating Between the Scylla and Charybdis of Prescribing Dietary

Protein for Chronic Kidney Diseases

Harold A. Franch and William E. Mitch ....

Nonalcoholic Fatty Liver Disease and Low-Carbohydrate Diets

Linda Wasserbach York, Swathy Puthalapattu, and George Y. Wu

Effects of Arsenic on Maternal and Fetal Health

Marie Vabter

Nutrient Biofortification of Food Crops

Kendal D. Hirschi

\section{Indexes}

Cumulative Index of Contributing Authors, Volumes 25-29

Cumulative Index of Chapter Titles, Volumes 25-29

\section{Errata}

An online log of corrections to Annual Review of Nutrition articles may be found at http://nutr.annualreviews.org/errata.shtml 